\title{
Energy, property, and the industrial revolution narrative
}

\author{
Stefania Barca * \\ Centro de Estudos Sociais, Universidade de Coimbra, Colégio S. Jerónimo, Largo D. Dinis, 3001-401 Coimbra, Portugal
}

\section{A R T I C L E I N F O}

\section{Article history:}

Received 17 September 2009

Received in revised form 1 March 2010

Accepted 17 March 2010

Available online 24 April 2010

Keywords:

Economic growth narrative

Energy inequalities

Environmental history

\begin{abstract}
A B S T R A C T
The Industrial Revolution (IR) story is the core of a mainstream economic history narrative of energy/development relationships, celebrating Modern Economic Growth (MEG) as the increase in per capita energy consumption in the last two centuries. Such a narrative emphasizes mineral technology and private property as the key elements of growth processes. I will criticize the above narrative, from a socio-environmental history perspective, for its inability to account for two crucial aspects of energy history: 1. the role of social power as key determinant in how energy sources are used and to what ends; 2 . the socio-ecological costs associated with the increase of energy consumption. I will then review Environmental History studies on energy/industrialization and highlight possible future developments in the field. The article makes a strong point for the need to look at energy transitions as social processes, and to include the unequal distribution of environmental, health, and social costs of mineral energy into global history narratives.
\end{abstract}

(c) 2010 Elsevier B.V. All rights reserved.

\section{Introduction}

Although its historiography dates back more than a century, there is still something hidden within (and more often by) the narrative of the Industrial Revolution (IR). One of the most powerful cross-field narratives concerning the 'rise of the western world' and its technoeconomic supremacy, the story of the IR is the core of a broader progressive narrative about the relations between energy patterns and Modern Economic Growth (MEG), including a number of implications about society/nature and north/south relationships. This narrative identifies modernity with an unprecedented increase in energy consumption, considered an undisputable accomplishment of European culture on behalf of humanity. Originating at the very 'energy mystique' that Watt's steam engine produced among contemporary observers (Greenberg, 1990), this idea informed a series of studies in Economic History published during the post-war and pre-energy crisis period, that have educated generations of students, shaping common perceptions of economic development in the industrial era.

In what follows, I will offer a critique of this mainstream MEG narrative, and some insights on how Environmental History has dealt with energy and the IR. My analysis is informed by the long-standing concern of Environmental History with the political meaning/use of historical narratives (Cronon, 1992; Hughes, 1995; Merchant, 2004; Redclift, 1995; Dovers, 2000). Though pointing to some faulties of the mainstream story of the IR, my critique is mostly concerned with what

Abbreviations: MEG, Modern Economic Growth; IR, Industrial Revolution; EH, Environmental History.

* Tel.: + 351239 855595; fax: + 351239855589.

E-mail address: sbarca@ces.uc.pt. is missing from that narrative - that is, with the way in which it systematically silences environmental and social costs and the global inequalities incorporated into current energy regimes.

1.1. Stealing Fire from the Gods: Energy and Property in Modern Economic Growth Narratives

The invention of the IR as a subject of historical investigation is generally attributed to Arnold Toynbee, who, writing at the end of the 19th century, based on two building blocks: classical political economy (the division of labor, in particular) and steam technology (Toynbee, 1960 [1884]). The two have been brought together in a variety of different narratives ever since: among them, those produced in the 1960s have been particularly relevant to the formation of common perceptions about 'modern growth' as a western pattern of development, based on techno-institutional superiority and the mastering of inanimate power (Deane, 1965). A landmark in the field, recently republished, D. Landes 2003 (1969) The Unbound Prometheus for example, launched a definition of the IR as the final victory of humanity (represented by the male hero who stole fire from the gods) from the constraints of 'natural' conditions, thanks to new technologies and social values (Landes, 2003 (1969)).

Such progressive mainstream story of industrialization rests upon a series of more or less implicit assumptions about society/nature and north/south relationships. In one of the most widely read histories of technology, for example, economic historian Joel Mokyr states that 'techniques (...) are analogues of species' so that 'changes in them have an evolutionary character'; the author even categorizes the idea of how to produce a commodity as the genotype and the actual technique utilized by the firm in producing it as the phenotype (Mokyr, 1990, $275 \mathrm{ff}$ ). The resort to biology comes after about 300 pages in which the book seeks to 
explain 'the difference between rich nations and poor nations', establishing that the ability of rich nations 'to control and manipulate nature and people for productive ends is superior'(ib. 3). No consideration is given to the relationships between individuals and social groups, geographic areas and 'nations', nor between any of them and the pieces of nature that they are manipulating (or are failing to manipulate) for superior ends. Progress, says the author, is the equivalent of a free lunch gained by exceptionally smart people. The possibility that free lunches might be stolen from someone else's table is not considered in the book.

Mostly, economic history studies on energy draw on Fred Cottrell's and Carlo Cipolla's seminal works (Cottrell, 2009 [1955]; Cipolla, 1962), which examined the whole human history with a few tracts of calculation, depicting shifts in energy-use patterns. Cipolla's view of the IR as 'the process by which a society acquired control over vast sources of inanimate energy', in particular, was enormously influential on more than a generation of scholars (Cipolla, 1973; Mathias, 2003). Conversely, the idea that change in energy systems is influenced by power relationships in society - as stated by Marc Bloch (1967) - has been mostly ignored in mainstream narratives of energy and industrialization.

Overall, among the many aspects of the IR, energy has been probably the least debated among historians. A general consensus has been reached that the essence of the IR consists in the fact that, as Pat Hudson wrote, 'no previous society had been able to escape the barriers which pre-industrial technology and culture placed on production' (Hudson, 1992, 2-3, emphasis added). Wide consensus exists among economic historians that, like the French Revolution, so the Industrial was a process of liberation: it was followed by dramatic change and suffering, but it was nonetheless necessary and positive, since it allowed the freeing of human potential from constraints both 'natural' (the solar energy flow) and 'un-natural' (the moral economy), finally allowing unlimited growth. By emphasizing this liberation of humanity by the means of a new energy system, the narrative of the IR necessarily comes to consider Capitalism as its hero (= Prometheus).

Technological and institutional ingenuity are universally treated in economic history textbooks as the two interrelated keys to the 'rise of the West' in the modern era. According to MEG narratives, in fact, the foundational moment of a development process is the individual appropriation of land, and/or other natural resources (water, oil, etc.), their 'liberation' from a previous state of un-certainty of property rights, implying their over- or under-exploitation, and their 'improvement' by technical innovation; the reference is generally to the experience of the English enclosures between the 17th and 18th centuries, celebrated in a consolidated historiography as the necessary prelude to the IR. Probably the most influential example of this line of explanation in the last decades has been that elaborated by Nobel Prize winner (in Economics) Douglass North and Robert Thomas in their theorization of the 'rise of the western world' (North and Thomas, 1973). Building on economist Harold Demsetz's view of the relations between property and economic development (Demsetz, 1967; Alchian and Demsetz, 1973), the authors defined modern growth as the 'break of the Malthusian trap', and ascribed it to institutional changes 'which by incentive direct man's efforts towards technological change and sustained productivity growth' (North and Thomas, 1994, 4). The use of the present tense ('direct') shows how the intent of the authors was not to give a historical explanation for the English IR, but rather to build a universal model of economic development capable of explaining how the latter 'occurs' in abstract terms. This is consonant with the tendency of Economic History as a discipline to consider itself as a branch of Economics, so gaining a more 'scientific' stature. As a result, the two causal explanations of modern growth - the emergence of private property and the energy shift - have mutually reinforced each other, producing a unified and powerful narrative of techno-institutional supremacy as the main cause of economic growth in northern countries.

Probably the best example of this progressive vision of energy/society relationships through time is E.A. Wrigley's account of the IR (Wrigley,
1988), in which mineral energy and private property institutions are systematically linked to each other as the fundamentals of capitalism. Acknowledged as a leading study on the IR from an energy-and-material flows perspective, Wrigley's work was informed by fairly optimistic (and implicitly anti-ecological) visions of future energy/economy relationships. Most of all, in fact, the book represented the shift to the mineral regime as a totally positive and costless process which allowed the liberation of 'humanity' from the limits of renewable energy flows, initiating a virtually limitless economic growth. The book incessantly highlighted how the non mineral - which he called the 'organic' - economy was 'necessarily severely inhibited by its energy budget' (5), and how this was the main difference between the old and the new energy regime.

In his zeal to highlight the conquest of mineral energy, Wrigley did not consider fossil fuels as limited resources, subject to diminishing returns. He completely overlooked the question of the time span in which the economic process is considered. And yet - like many other economic narratives before and after - this study had profound implications in terms of speculations about the present and future relationships between economy and ecology, and between rich and poor countries. As the author himself stated in the Introduction, the book aimed to highlight the events 'that brought into being a world (...) that no longer follows the rhythms of the sun and the seasons; a world in which the fortunes of man depend largely upon how he himself regulates the economy and not upon the vagaries of weather and harvest; a world in which poverty has become an optional state rather than a reflection of the necessary limitations of human productive powers; a world increasingly free from major natural disasters, but in which human folly can mean utter and total destruction' (6). The book is thus posited within a discursive framework which: 1) considers nature as a pure obstacle to human life and technology as an absolute good; 2) sees poverty as invariably the product of human will (not of ecological or power relationships); 3) inexplicably erases disasters - either naturally or socially produced - from the sphere of experience of modern humanity (and so doing obliterates most socio-ecological concerns with one coup); and 4) attributes the eventuality of total destruction to human folly, that is an unpredictable but also unlikely factor, and not to structural characteristics of the modern world economy. This is a consequential logic for a book which devotes no attention to the social costs related to MEG in any form, and which represents the contemporary world economy as the fortunate result of a major energy shift occurred two centuries ago, whose heredity modern humanity cannot refuse, only acknowledge. In fact, the book's purpose is to help the reader in finding answers on the causes of the IR, all converging towards one particular explanation: mineral energy.

Not only did Wrigley's narrative overlook the problem of the future exhaustion of mineral sources, but, even more importantly, it lacked any account for social and environmental costs, either past, present or future. The clearest example is the way in which the author applied the same positive vision to the agricultural sector: he claimed that the industrialization of agriculture not only postponed the logic of diminishing returns, but invalidated it completely. Wrigley paid no attention to energy efficiency, either in agriculture or in the economic system in general - not to mention the many other costs of fossilfuelled agriculture, from soil exhaustion and pesticide contamination to dependence on expensive industrial inputs and the need for subsidies on the part of governments.

Despite forming a substantial portion of the history of industrial societies, neither atmospheric pollution, local and global, nor living and working conditions in the coalfields and factories, nor ill-health and environmental degradation related to the extraction of mineral resources preoccupied the author, who completely omitted such aspects from his account of the English IR. As such, the book offers a notable example of the MEG paradigm: in such interpretation of energy/economy relationships, history is narrated as the ability of 
Man - the European masculine collective entity taken as a simplification of the entire humanity (and of how the entire humanity should look like) - to grow rich.

Published more than 20 years ago, the above book might be considered a late exemplar in a tradition of studies imprinted to a post-war optimistic vision of energy and economic development. Two pillars sustain this mainstream MEG narrative: Energy (in particular, the shift from 'organic' to 'inorganic', or from 'animate' to 'inanimate' sources) and Institutions, especially the affirmation of exclusive property rights. As such, the story of Modern Economic Growth has long dominated development discourses, and social perceptions of both society/nature and of north/south relationships.

MEG narratives, however, do have their counterpart in a global ecological narrative of energy transitions and industrialization, emphasizing the ecological contradictions of unlimited growth and especially critiquing the disregard of mainstream economics for natural limits (Kapp, 1971 [1950]; Georgescu-Roegen, 1976; Rifkin, 1980; Martinez Alier, 1987; Daly, 1991; Boulding, 1992; Norgaard, 1994; Ayres, 1994). At least since the early 1970s, the two narratives have mostly proceeded in parallel, the 'entropic' story being less influential in academic and political terms than the 'progressive'. Nevertheless, MEG authors have generally paid little or no attention to ecological critiques, and have recently restated their theses unchanged; nor has the mainstream MEG plot been challenged from within the discipline, as more recent textbooks in economic history show. At the time I was writing this article, two world economic histories have appeared in print, both by Princeton University Press. First came D. Acemoglu's edited collection of essays on Modern Economic Growth: an enquiry on 'why some countries failed to take advantage of the new technologies and production opportunities' brought about by the IR (Acemoglu, 2008). The answer being, as stated by the editor himself in the concluding chapter, that the poor countries 'have not managed to undergo the requisite structural transformations and thus lack the type of financial relations, the appropriate skills, or the types of firms that are conducive to the adoption of new technologies' (864). Despite the amount of recent empirical and theoretical work cited in the volume, the interpretative paradigm of MEG has not changed substantially from its early formulation: the explanation of 'our prosperity today' being the right combination of institutional and technological change achieved by European societies sometime in their early modern to modern history, and the IR still being the starting point of a progressive change potentially improving the conditions of the entire humanity. The second book (Clark, 2009), seeks to answer the same question of the former, and, albeit following a rather peculiar line of investigation, arrives at a very similar answer: culture - i.e. innovation due to 'hard work, rationality, and education' - explains the IR, and the IR was what made all the difference in world history. Pushing previous MEG narratives to the extreme, Clark goes so far as to argue that it was natural selection of the human species that accounted for the successful performance of some nations over others during the modern era (166-67).

Though most of the books cited above tend to depict the present as the result of the best possible historical development, such idea is only understandable from the perspective of university towns in northern countries, while much information coming from the outside world reminds us that this is not indeed the case. Faced by increasing inequalities and vulnerability as the two major issues at stake even in highly established literature such as World Bank and UN reports, the above books have responded by reaffirming the superiority of (northern) Europeans in growing rich before others, and (more or less) explicitly blaming it on the poor for their inability at imitating the white Man's model. The idea that Modern Economic Growth and poverty in different parts of the world are somehow related to each other through unequal relations of resource appropriation and destruction is, more than ever, pushed out of the mainstream.
1.2. Prometheus Revisited: The Industrial Revolution in Environmental History

How have environmental historians dealt with the MEG paradigm and the mainstream IR story? Do they offer a coherent alternative narrative on global energy/society relationships?

As a new field of studies, Environmental History (EH) was born out of the 1970s environmental movement, and founding scholars were mostly interested in tracing the origins of the current ecological crisis, in the US as in Europe (Worster, 1979; Merchant, 1980; Cronon, 1983; Brimblecombe and Pfister, 1990). Some of these early Environmental History works were directly concerned with energy transitions, and were partly consistent with Wrigley's interpretation of the IR - in particular, the notions of the organic and the mineral economy, and how the latter allowed overcoming traditional limits for economic and physical growth. In fact, Wrigley's book itself might be seen as participating in a persisting intellectual effort in understanding the material basis of 'poverty and progress': a scholarly thread in which also anthropologists and geographers have long figured (Burke and Pomeranz, 2009; Clapp, 1994; Crosby, 2006; Debeir et al., 1991 [1986]; Malanima, 2006; Malanima et al., 2007; Pomeranz, 2000; Sieferle, 2001 [1982] Simmons, 2008; Smil, 1994, 2008, Wilkinson, 1973). Aside from their common concern with the energy and material sources of wealth (a concern which most authors hold against the mainstream of respective disciplinary fields) these works show various grades of representation of the socio-environmental costs of industrialization - Wrigley being the only remarkable exception. I will now review some of these early environmental histories of energy, and then show how EH has come to expand the energy discourse by explicitly addressing the social and environmental costs on both the local and the global scale.

Probably the most methodologically innovative work within this group, as an EH alternative explanation of energy and economic growth, was a French book entitled Les servitudes de la puissance (Debeir et al., 1991 [1986]). Taking into account complexity theory, and integrating it with social, economic and technology history, the authors - J.C. Debeir, J.P. Déleage and C. Émery - offered an original socio-ecological approach to energy transitions. Inspired by French bio-economist René Passet (Passet, 1994 [1979]), the authors located human history within a theoretical framework interlacing social and ecological regulation; the book was thus centered on the evolution of historical entities called 'energy systems'. The concept of energy system incorporates the authors' idea that the interdependencies between modes of production, social formations and the biosphere - the three levels on which the whole human activity takes place - should be analysed in a unique narrative.

Energy systems are formed not only of the ecological and technological aspects of energy sources but also, and equally importantly, 'of the social structures for the appropriation and management of these sources and converters'. An energy system - according to the authors - 'is the original combination of diverse converter chains which draw on determined sources of energy and depend on each other, initiated or controlled by classes or social groups which develop and consolidate on the basis of this control' (5, emphasis added). Such a definition allows us to see the social complexities of energy systems in their historical evolution: 'the dynamic of energy systems - the authors wrote - obeys a more general rationality, that of the social formation of which it is a part; it therefore bears the mark of the pharaoh's political religious rule, of the feudal lord, or more recently of the bourgeois state' (7).

The book, however, was not centered on the IR, which it located within a longer history of energy shifts since antiquity; the authors did attribute to the IR a key role in changing human history, but they did not frame this shift as a positive and costless accomplishment of 'humanity'. The crucial aspect of the IR they highlighted was the higher and higher levels of technical specialization and capital 
investments required by mineral energy sources. Since the IR, they noted, 'energy would become a matter for investors, scientists and engineers. It would constitute an independent and autonomous sector that would play a decisive role in regulating the new economy' (87). The second part of the book was in fact mostly devoted to the question of nuclear power: a question which played an important role in the birth of Environmental History as a discipline, especially in Europe (Radkau, 2008 [2002]).

Though highly promising for its transdisciplinary, holistic approach to energy history - interlacing social with ecological dynamics through a political economy explanation - the methodology of complexity theory adopted by Debeir et al. has not been widely followed in EH studies thereafter. Nevertheless, the concept of 'energy system' was essential to early EH works on the IR (Sieferle, 1990), which tended to follow a 'resource scarcity' or 'energy and materials flows' approach (Clapp, 1994; Sieferle, 2001 [1982]; Wilkinson, 1988); some of these studies also started to give attention to environmental and social costs of the urban/industrial way of life, such as entropy, pollution, public health, resource exhaustion. B.W. Clapp's Environmental History of Britain since the IR, for example, represented the shift to coal in thermodynamic fashion: mineral energy, the author pointed out, is the only natural resource which, once used, is lost forever. Though such perspective was only partially correct, since also renewable resources like forests or fish can be totally lost if overused, the fact remains that this was probably the first Environmental History narrative on the IR. The book was almost entirely devoted to the evolution of technical and institutional devices towards energy (and materials) conservation and to anti-waste policies.

On the other side of the Atlantic, EH's reflections on the IR started with Ted Steinberg's, 1986 review essay 'An ecological perspective on the origins of industrialization'. The transformation of the environment - Steinberg wrote - 'perhaps the most visible manifestation of industrial change' had remained outside of historical research so far. The IR had 'reworked the earth's landscape, altering the foundations of a society based on agriculture and placing it on the road to modern economic development. Humankind's relationship with the natural world was profoundly affected. New sources of energy and technology were developed, different ways of farming and feeding the population emerged - all that accompanied the shift to the industrial mode of production. The IR was part of a tremendous ecological restructuring, a new and significant chapter in the earth's Environmental History'. (261) Such perspective could open a new, crucial field of investigation for environmental historians. 'Because industrialization involved a significant shift in humankind's relationship with nature', Steinberg continued, 'an ecological perspective may help us discover the roots of that change' (261-62).

A major point in Steinberg's analysis, concerning energy and industrialization, was that waterpower, not steam, had been the energy source relevant to industrialization. 'Rivers, not steam engines, should be the focus for studying early industrialization. A new technology and material culture evolved to more efficiently exploit river resources. The legal system also changed, encouraging the manipulation of water for greater energy and profits. Those developments were all part of the long process whereby nature was increasingly conceived as discrete bundles of commodities - of wood, land, and water. The IR had redefined the environment; it was now a vast "natural resource" (273).

The article thus ended by suggesting that the causes of the IR be sought in humanity's place within the natural context. Perhaps more importantly, the connection between institutions and technology was starting to being posited in a new light: not the one of a progressive path towards resource improvement and wealth, but the one of nature's transformation into capital, with the increasing socioenvironmental costs associated to such transformation. Roughly a decade later, US environmental historian Donald Hughes also highlighted the need to replace mainstream world history narrative of 'development' with a different organizational principle, that of ecology, including the account of limits and costs of economic growth (Hughes, 1995). Such line of investigation, dealing with the "big picture' of energy transitions in the very long durée, has tended in the past decade to converge towards a new sub-field called World Environmental History (Crosby, 1972, 1986; Diamond, 1997, 2005; Hornborg, 2006; Hughes, 2000, 2002; Marks, 2002; McNeill, 2000; Pomeranz, 2000; Burke and Pomeranz, 2009; Ponting, 1992; Radkau, 2008 [2002]; Simmons, 2008).

On a more limited scale and scope of investigation, assuming the environmental perspective, and choosing the 'down to earth', or 'from the ground up' (Steinberg, 2002) approach, has implied for environmental historians to be able to see what mainstream economic narratives tended to hide. Probably the most innovative work in this sense was given by Steinberg himself with his history of industrialization in New England (Steinberg, 2004 [1991]). Interestingly enough, the book was centered on the historical role played by an energy source different from coal: waterpower. Breaking with economic history representations of the IR, the author assumed the perspective of American environmentalist H.D. Thoureau, whose 1839 trip on the Merrimack River formed one of the earliest acknowledgments of the industrial transformation of New England. This approach allowed to show how 'industrial capitalism is not only an economic system, but a system of ecological relations as well' (Steinberg, 2004 [1991], 11). Furthermore, social relationships were included in the author's approach, which assumed that different forms of control over nature produce different forms of social control - a perspective which environmental historians owe to Donald Worster's pathbreaking study on water and power in the US West (Worster, 1985).

The book can be considered the first example of a coherent EH narrative of the IR. It showed how a new waterscape along the Merrimack river, the 'most celebrated river valley in America's early industrial history' (50), was produced towards the end of the 18th century and the early 19th century, by the means of revolutionary changes in cultural norms and legal rules. In the process, a new, 'instrumental conception of water centered primarily on economic growth' emerged (23). Most importantly, including a business history perspective, the story was centered around the Boston Associates company, vividly depicted in the process of reaching out over the waterscape 'to change rural into urban, to turn water into power and production', in the end totally reshaping the valley to fit 'the needs of large scale textile production' (77). Such massive transformation, the author pointed out, could only be accomplished by the means of market rules and water engineering science - both extensively employed by the Boston Ass. to eventually form the so called Waltham-Lowell system of textile milling. The company, however, also generated massive social change and conflict, which crucially involved historical subjects excluded by the economic benefits of industrialization and dispossessed of their traditional share of water control: upriver communities, agriculturalists, and fish. Large parts of the book were thus devoted to the struggle over water among competing users and the social costs generated along the process of industrialization, among which the destruction of fisheries and the spread of infectious disease associated with water pollution. Throwing MEG narrative's energy triumphalism over its head, the author concluded how the 'unquestioned attitude of dominance toward nature is among the most powerful legacies of industrialization', though such belief might turn out to be 'little more than an illusion' (271).

Another landmark EH study of energy and industrialization followed a few years later: Richard White's The Organic Machine, centered on the transformation of the Columbia River during the 19th and 20th centuries (White, 1995). The book opened up a methodologically new approach to energy history: the river is seen not as a mere energy carrier but as an active historical force, interacting in inextricable ways with human agency through work - both human 
and natural. In White's original perspective, it is labor, rather than the conquest of nature, what 'involves human beings with the world so thoroughly that they can never be disentangled' (7). Looking at energy history from the vantage point of the Columbia rapids and portages, in fact, allowed the author to see how energy and power, 'the natural and the cultural', are mixed as social facts. Not a history of industrialization strictly speaking, the book showed instead the whole complex of changing interrelationships between the Columbia River and the different human groups living and working along its banks. Portages, steamboats, canneries, fish gilnettes and fish wheels, hydropower stations and nuclear plants are all part of a unique narrative of energy shifts, which are shown as the social response to both opportunities and challenges posed by the natural environment. At the same time, human groups and their shifting power relations are vividly depicted as the result of technical 'improvements' in the ability to tame the river's energy, crucially implying new forms of appropriation.

Generally speaking, however, environmental historians have focused on the consequences more than the causes of the IR. Despite being still marginal to the mainstream of the discipline and to academic teaching, in the last two decades environmental historians have worked from within the profession, producing a remarkable (and highly needed) series of counter-stories on industrialization and urbanization in a number of places, offering an invaluable contribution in this respect (Barca, 2007; Bernhardt and Massard-Guilbaud, 2002; Bowler and Brimblecombe, 2000; Cronon, 1994; Hamlin, 1990, 1998; Melosi, 2001; Newell and Watts, 1996; Paavola, 2002; Rosen, 2003; Sellers, 1997; Sheail, 2002; Tarr, 1996, 2003). An early example of such different narrative of industrialization was - to stay within the energy question - Franz J. Brueggemeier's 1992 article on the Ruhr region, that clearly showed the high social costs of coal extraction and refinement in terms of human health (typhoid fever), environmental and resource depletion (death of the river as a biological entity); air pollution associated with coal burning. The article also emphasized the clear orientation of institutions and the legal system towards the protection of industry against all odds; and the irreversibility of changes resulting from industrialization, not only in terms of environmental degradation, but also as loss of other sources of income for the local population.

Environmental History offers an intrinsically alternative version of growth processes in the last two centuries. All authors have shown a steady concern with pollution, public health, and the depletion of environmental resources associated with the urban/industrial mode of life. The birth of Urban EH, not by chance, was influenced by Martin Melosi's work on energy in American history (Melosi, 1985), which started a new way of looking at cities as not only part of larger energy systems and material flows, but also of broader political communities with their peculiar choices in the production and distribution of both wealth and waste; the same Author has also shown the key relationship linking the dimension of social conflict and environmental justice to that of energy history (Melosi, 2001). Looking at the IR in its very birthplace, Harold Platt has, more recently, blended together technology and industrial ecology with power inequalities and social conflicts (Platt, 2005). Studies on the oil economy and ecology, emerging in the US in the last ten years, can be also referred to this line of investigation, whose peculiarity is that of knitting together energy use, social metabolism and power conflicts (Black, 2000; Melosi and Pratt, 2007; Santiago, 2006). All these works tell a counterstory of the age of fossil fuels, which incorporates the point of view of places, bodies, labor and environmental justice.

Despite remaining the factory system a somehow eluded topic for environmental historians, nevertheless research on industrialization as an ecological process has persisted throughout the last twenty years, and is now evolving in new directions. One is being developed in Europe, at the border between Environmental History and ecological economics, and is known under the label of Social (or
Industrial) Metabolism: that is, 'an ecological-economic history concerned with the physical assessment of the impacts of the human economy' (Martinez Alier and Schandl, 2002, 175). In the words of F. Krausmann, H. Schandl and R.P. Sieferle, Industrial Metabolism studies, 'conceptualize industrialization as a stepwise process of decoupling the supply of energy from land related biomass and from human labor on the land. This has caused a shift in society's energy strategy away from tapping into flows of renewable energy towards the exploitation of large but nevertheless finite stocks of fossil energy' (Krausmann et al., 2008, 188). Research on Industrial Metabolism, however, is basically concerned with the 'new kinds of sustainability problems and environmental impacts' associated with the fossil energy regime. The major difference between agrarian and industrial societies, according to these authors, is that, while in agrarian societies, sustainability problems arise on the side of resource inputs and overexploitation of resources, in industrial societies 'output-related environmental impacts, habitat loss and social inequality impose a major threat to sustainability' (199). This difference, however, is only temporary, because resource input limits are destined to grow more important in a fossil-based economy. Sustainability problems of the fossil regime (energy scarcity and global pollution in particular) are also problems of distribution, which reinforce global inequalities: there might be not enough resources available for all world population to grow rich, and in the meanwhile, major disasters related to climate change and toxic waste disposal will disproportionately affect the poor. The Authors thus conclude advocating the need 'for a new, sustainable, industrial socio-ecological regime with lower per capita material and energy turnover and a lower share of non-renewable energy and materials' (199). Framed within sustainability concerns and including the account of global and social inequalities in thermodynamic terms, Social Metabolism studies offer a radically revised version of the IR story (Anderberg, 1998; Douglas et al., 2002; Fischer-Kowalski and Haberl, 2007; Hornborg, 2006; Iriarte-Goñi and Ayuda, 2008; Krausmann and Haberl, 2002; Kuskova et al., 2008; Schandl and Schulz, 2002,).

At the same time, important efforts have been made since the late 1990s to incorporate environmental concerns within World-System Theory, as testified by two special issues of the Journal of World System Research (Bergesen and Parisi, 1997; Jorgenson and Kick, 2003), plus a number of collective books published by World-System scholars in the last decade (Chew, 2008; Goldfrank et al., 1999; Dunlap et al., 2002; Hall, 2000; Jorgenson and Kick, 2006). Born in the 1970s from the rejection of mainstream modernization narratives that is the idea that poverty is due to lack of adequate technology and institutions in poor countries - and based on a mixed historicalsociological approach, World-System Theory has been developing an enduring interest towards the ecological dimension of unequal exchange (Roberts and Grimes, 2002). Of particular relevance here are Bruce Podobnik's studies on inequality in energy history and policy (Podobnik, 2002, 2005), emphasizing two aspects which do not figure in mainstream accounts of energy history: 1) the uneven distribution of costs and benefits of energy use at the global level, and 2 ) the relevance of the social (organized protest in particular) in influencing energy trends and policies. Furthermore, the worldsystem perspective has been successfully applied to the topic of the IR itself in Alf Hornborg's work (Hornborg, 2001, 2007), where industrialization comes to be read as the appropriation of (natural) space and (labor) time on the part of 18th and 19th centuries British elites, a process which displayed itself on the global as well as on the local scale (Hornborg, 2006).

Recent publications blending the EH and the WST approach (Hornborg, 2006, 2007; Moore, 2003) as well as scientific events such as the world-system session held at the first World Environmental History conference of Copenhagen 2009 - show that the times are probably mature for a crossfertilization between these two approaches. 
To sum up, the incorporation of the social perspective, and of the inequality issue in particular, seems to be a new and promising direction for the Environmental History of energy. Linking energy regimes to property regimes in a unified narrative would allow to incorporate global and social inequalities within Industrial Metabolism; to cross the factory gates and investigate the shopfloor and its human ecology; to put labor, human bodies and landscapes into the story of energy transitions. By developing energy history through these lines of investigation, a new interpretive scenario of economic growth might emerge: one able to materially articulate the 'big picture' of ecology/economy relationships with people's lives and their environment. How far will this new scenario succeed in being incorporated within mainstream narratives of Modern Economic Growth is a crucial question for the emergence of an alternative vision of 'development' among future generations of students, scholars and decision-makers.

\section{Conclusions}

This article has argued that mainstream narratives of the IR represent economic change in the last 200 years as a story of continuous progress and systematically ignore issues of the related social and ecological costs; in addition, the article has shown how approaches from Environmental History have contributed to expand this narrow viewpoint. Ecological Economics has been a powerful instrument for many environmental historians in order to counterargue the dominant progressive view of 'Modern Economic Growth', and these two disciplines have also frequently crossfertilized each others, as shown by the special section published by this journal several years ago (Martinez Alier and Schandl, 2002), together with a number of sporadic articles with an EH focus (e.g. Cusso' et al., 2006; Hornborg, 2006; Krausmann et al., 2008; Kuskova et al., 2008).

I hope this article has made clear how it is not a simple return to social history and Marxist views of the IR what is needed, but a new and more comprehensive narrative, systematically integrating the environmental costs of Modern Economic Growth and their social impact. Such an approach would ultimately overcome the logic of externalities which has dominated much of economic history so far - namely, its tendency to account only for the gains, leaving the losses for separate accounts by social and environmental historians.

A few, powerful concepts can be extrapolated as representative of MEG narratives: the idea that economic growth rests on the perpetual increase of fossil energy consumption; that environmental and social costs are negligible; that natural resources need to be put under private property regimes in order to become productive. Since historical narratives always influence present visions (and vice versa), such ideas continue to inform international development policies, with dreadful repercussions on the environment, health, and social justice. As the authors of a recent review article on the impact of oil policies have pointed out, 'Although the case for the economic and political benefits of increased production and control over oil has been clearly articulated, the environmental, health, and social costs of increased oil flows are largely absent from government policy deliberations. And perhaps more importantly, the actual distribution of costs and benefits of increased oil production among countries, communities, and individuals is almost completely absent from public discourse (O'Rourke and Connolly, 2003, emphasis added).

Energy policies of the present era have been largely influenced by narratives of Modern Economic Growth and by the Industrial Revolution story. It is time to acknowledge that energy policies are socioenvironmental, not just economic, problems. They are a relevant part of what political ecologists call 'environmental justice' issues - that is, the unequal distribution of the costs and benefits of economic growth among different social groups and among different areas. Economic growth based on the increase of fossil fuel use has been a profoundly uneven process, increasing global inequalities and negatively affecting the lives of powerless multitudes, future generations and the non human world, through the impairment of their living and working environments: as such, it cannot be the answer to poverty and it must be put under severe re-thinking.

\section{Acknowledgments}

This article is a revised version of a paper which I delivered at the UC Berkeley Environmental Politics Workshop in November 2007, in the course of a 'S.V. Ciriacy Wantrup' postdoctoral fellowship in Natural Resource Economics and Political Economy. I wish to thank Nancy Peluso, Ben Gardener and all the participants in the colloquium for their insightful comments. Thanks also to Giorgos Kallis and Jouni Paavola for their suggestions on an earlier draft, and to the three anonymous referees for their very helpful comments.

\section{References}

Acemoglu, D., 2008. Introduction to Modern Economic Growth. Princeton U.P., Princeton. Alchian, A.A., Demsetz, H. 1973. The property rights paradigm. Journal of Economic History $1,16-27$

Anderberg, S., 1998. Industrial metabolism and the linkages between economics, ethics and the environment. Ecological Economics 24, 311-320.

Ayres, R., 1994. Information, Entropy, and Progress: A New Evolutionary Paradigm. AIP Press, Woodbury, NY.

Barca, S., 2007. Enclosing the river. Industrialization and the property rights discourse in the Liri Valley (South of Italy), 1806-1916. Environment and History 1, 3-23.

Bergesen, A., Parisi, L., 1997. Discovering the environment. Journal of World-Systems Research 3, 364-368.

Bernhardt, C., Massard-Guilbaud, G. (Eds.), 2002. The Modern Demon. Pollution in Urban and Industrial European Societies. Presses Universitaires Blaise-Pascal, Clermont-Ferrand.

Black, B., 2000. Petrolia. The Landscape of America's First Oil Boom. Johns Hopkins University Press, Baltimore.

Bloch, M., 1967. Land and Work in Medieval Europe. Univ. of California Press, Berkeley.

Boulding, K., 1992. Towards a New Economics: Critical Essays on Ecology, Distribution, and Other Themes. Edward Elgar, Aldershot and Brookfield.

Bowler, C., Brimblecombe, P., 2000. Control of air pollution in Manchester prior to the Public Health Act, 1875. Environment and History 1.

Brimblecombe, P., Pfister, C. (Eds.), 1990. The Silent Countdown. Essays in European Environmental History. Springer-Verlag, Berlin.

Burke III, E., Pomeranz, K. (Eds.), 2009. The Environment and World History. University of California Press, Berkeley.

Chew, S.C., 2008. Ecological Futures: What History Can Teach Us. Altamira Press, Lanham, MD.

Cipolla, C.M., 1962. The Economic History of World Population. Penguin Books, Baltimore.

Cipolla, C.M., 1973. Introduction, in Id. (Ed), The Industrial Revolution. Glasgow: Fontana/Collins.

Clapp, B.W., 1994. An Environmental History of Britain since the Industrial Revolution. Longman, London and New York.

Clark, G., 2009. A Farewell to Alms. A Brief Economic History of the World. Princeton U.P, Princeton.

Cottrell, F., 2009 [1955]]. Energy and society. In: Cleveland, Cutler J. (Ed.), Encyclopedia of Earth. Environmental Information Coalition, National Council for Science and the Environment, Washington, D.C.. [Published in the Encyclopedia of Earth March 4, 2009; Retrieved March 1, 2010] http://www.eoearth.org/article/Energy_and_Society: Chapter_2:_Organic_Energy_and_the_Low-Energy_Society.

Cronon, W., 1983. Changes in the Land: Indians, Colonists, and the Ecology of New England. Hill and Wang, New York.

Cronon, W., 1994. Nature's Metropolis: Chicago and the Great West. W.W. Norton, New York

Cronon, W., 1992. A place for stories. Nature, history and narrative. Journal of American History 4, 1347-1376.

Crosby, A., 1972. The Columbian Exchange; Biological and Cultural Consequences of 1492. Greenwood, Westport, CT

Crosby, A., 1986. Ecological Imperialism: The Biological Expansion of Europe, 900-1900. Cambridge University Press, Cambridge and New York.

Crosby, A., 2006. Children of the Sun. A History of Humanity's Unappeasable Appetite for Energy. W.W. Norton \& Company, New York and London.

Cusso', X., Garrabou, R., Tello, E., 2006. Social metabolism in an agrarian region of Catalonia (Spain) in 1860-70. Flows, energy balance and land use. Ecological Economics 58, 49-65.

Daly, H.E., 1991. Steady-state Economics. Island Press, Washington, D.C.

Deane, Ph., 1965. The First Industrial Revolution. Cambridge University Press, Cambridge, UK.

Debeir, J.C., Deleage, J.P., Emery, C., 1991 [1986]]. In the Servitude of Power: Energy and Civilization through the Ages. Zed Books, London.

Demsetz, H., 1967. Toward a theory of property rights. The American Economic Review 2, 347-359.

Diamond, J., 1997. Guns, Germs, and Steel: The Fates of Human Societies. W.W. Norton, New York.

Diamond, J., 2005. Collapse: How Societies Choose to Fail or Succeed. Viking, New York. 
Douglas, I., Hodgson, R., Lawson, N., 2002. Industry, environment and health through 200 years in Manchester. Ecological Economics 41, 235-255.

Dovers, S., 2000. On the contribution of environmental history to current debate and policy. Environment and History 2, 131-150.

Dunlap, R.E., Buttel, F.H., Dickens, P., Gijswijt, A. (Eds.), 2002. Sociological Theory and the Environment. Classical Foundations, Contemporary Insights. Rowman \& Littlefield Publishers, Lanham, Boulder, New York, Oxford.

Fischer-Kowalski, M., Haberl, H., 2007. Socioecological Transitions and Global Change: Trajectories of Social Metabolism and Land Use. Edward Elgar, Cheltenham, UK.

Georgescu-Roegen, N., 1976. Energy and Economic Myths: Institutional and Analytical Economic Essays. Pergamon Press, New York.

Goldfrank, W.L., Goodman, D., Szasz, A. (Eds.), 1999. Ecology and the World System. Greenwood Press, Westport, CT.

Greenberg, D., 1990. Energy, power and perceptions of social change in the early nineteenth century. The American Historical Review 3, 693-714.

Hall, T. (Ed.), 2000. A World-Systems Reader: New Perspectives on Gender, Urbanism, Culture, Indigenous Peoples, and Ecology. Rowman and Littlefield, Lanham.

Hamlin, C., 1990. A Science of Impurity: Water Analysis in Nineteenth Century Britain. University of California Press, Berkeley.

Hamlin, C., 1998. Public Health and Social Justice in the Age of Chadwick: Britain, 18001854. Cambridge University Press, Cambridge and New York.

Hornborg, A., 2001. The Power of the Machine: Global Inequalities of Economy, Technology, and Environment. Alta Mira Press, Walnut Creek, CA.

Hornborg, A., 2006. Footprints in the cotton fields: the IR as time-space appropriation and environmental load displacement. Ecological Economics 59, 74-81.

Hornborg, A., 2007. The World System and the Earth System. Left Coast Press, Walnut Creek.

Hughes, D., 1995. Ecology and development as narrative themes of world history. Environmental History 1, 1-16.

Hughes, D. (Ed.), 2000. The Face of the Earth: Environment and World History. M.E. Sharpe, New York.

Hughes, D., 2002. An Environmental History of the World: Humankind's Changing Role in the Community of Life. Routledge, London.

Iriarte-Goñi, I., Ayuda, M.I., 2008. Wood and industrialization evidence and hypotheses from the case of Spain, 1860-1935. Ecological Economics 65, 177-186.

Jorgenson, A.K., Kick, E.L., 2003. Globalization and the environment. Journal of WorldSystems Research 2, 195-203.

Jorgenson, A., Kick, E. (Eds.), 2006. Globalization and the Environment. Brill, Leiden.

Kapp, K.W., 1971 [1950]]. The Social Costs of Private Enterprise. Schocken Books, New York.

Krausmann, F., Haberl, H., 2002. The process of industrialization from the perspective of energetic metabolism. Socioeconomic energy flows in Austria 1830-1995. Ecological Economics 41, 177-201.

Krausmann, F., Schandl, H., Sieferle, R.P., 2008. Socio-ecological regime transitions in Austria and the United Kingdom. Ecological Economics 65, 187-201.

Kuskova, P., Gingrich, S., Krausmann, F., 2008. Long term changes in social metabolism and land use in Czechoslovakia, 1830-2000: an energy transition under changing political regimes. Ecological Economics 68, 394-407.

Landes, D., 2003 (1969)). The Unbound Prometheus. Technical Change and Industrial Development in Western Europe from 1750 to the Present. Cambridge University Press, Cambridge (UK) and New York.

Malanima, P., 2006. Energy crisis and growth 1650-1850: the European deviation in a comparative perspective. Journal of Global History 1, 101-121.

Malanima, P., Gales, B., Kander, A., Rubio, M., 2007. North versus south: energy transition and energy intensity in Europe over 200 years. European Review of Economic History 2, 219-253.

Marks, R., 2002. The Origins of the Modern World: A Global and Ecological Narrative. Rowman \& Littlefield, Lanham, MD.

Martinez Alier, J., 1987. Ecological Economics: Energy, Environment, and Society. Basil Blackwell, New York.

Martinez Alier, J., Schandl, H., 2002. Special section: European environmental history and ecological economics. Ecological Economics 41, 175-176.

Mathias, P., 2003. Energy and the industrial revolution. In memoriam - Carlo M. Cipolla. Rivista di Storia Economica 1, 109-134

McNeill, J.R., 2000. Something New under the Sun. An Environmental History of the Twentieth-century World. Norton, New York.

Melosi, M.V., 1985. Coping with Abundance: Energy and Environment in Industrial America. Temple University Press, Philadelphia.

Melosi, M.V., 2001. Effluent America: Cities, Industry, Energy, and the Environment. University of Pittsburgh Press, Pittsburgh.

Melosi, M.V., Pratt, J.A., 2007. Energy Metropolis: An Environmental History of Houston and the Gulf Coast. University of Pittsburgh Press, Pittsburgh.

Merchant, C., 1980. The Death of Nature: Women, Ecology and Scientific Revolution. Harper\&Row, San Francisco.

Merchant, C., 2004. Reinventing Eden. The Fate of Nature in Western Culture. Routledge, New York and London.

Mokyr, J., 1990. The Lever of Riches. Technological Creativity and Economic Progress. Oxford University Press, New Yorl and Oxford.

Moore, J., 2003. The modernworld-system as environmental history? Ecology and the rise of capitalism. Theory and Society $32,307-377$.
Newell, E., Watts, S., 1996. The environmental impact of industrialisation in South Wales in the nineteenth century: 'Copper Smoke' and the Llanelli Copper Company. Environment and History 2, 309-336.

Norgaard, R., 1994. Development Betrayed: The End of Progress and a Coevolutionary Revisioning of the Future. Routledge, London and New York.

North, D.C., Thomas, R., 1973. The Rise of the Western World. A New Economic History. Cambridge University Press, Cambridge.

North, D.C., Thomas, R.P., 1994. An economic theory of the growth of the western world. In: O'Brien, P.K. (Ed.), The Industrial Revolution in Europe, I. Blackwell, Oxford.

O'Rourke, D., Connolly, S., 2003. Just Oil? The distribution of environmental and socia impacts of oil production and consumption. Annual Review of Environment and Resources 28, 587-617.

Paavola, J., 2002. Water quality as property: industrial water pollution and common law in the nineteenth century United States. Environment and History 8, 295-318.

Passet, R., 1994 [1979]]. L'Economique et le Vivant. Economica, Paris.

Platt, H.L., 2005. Shock Cities: The Environmental Transformation and Reform of Manchester and Chicago. University of Chicago Press, Chicago.

Podobnik, B., 2002. Global energy inequalities: exploring the long-term implications. Journal of World-Systems Research 2, 252-274.

Podobnik, B., 2005. Global Energy Shifts: Fostering Sustainability in a Turbulent Age. Temple University Press, Philadelphia.

Pomeranz, P., 2000. The Great Divergence: China, Europe and the Making of the Modern World Economy. Princeton University Press, Princeton, NJ.

Ponting, C., 1992. A Green History of the World: The Environment and the Collapse of Great Civilizations. St. Martin's Press, New York.

Radkau, J., 2008 [2002]]. Nature and Power: A Global History of the Environment. Cambridge University Press, Cambridge and New York.

Redclift, M., 1995. In our own image. The environment and society as global discourse. Environment and History 1,111-123.

Rifkin, J., 1980. Entropy: a New World View. Viking Press, New York.

Roberts, J.T., Grimes, P.E., 2002. World-system theory and the environment: toward a new synthesis. In: Dunlap, R.E., Buttel, F.H., Dickens, P., Gijswijt, A. (Eds.), Sociological Theory and the Environment. Classical Foundations, Contemporary Insights. Rowman \& Littlefield, Lanham, pp. 167-194.

Rosen, C.M., 2003. 'Knowing' industrial pollution: nuisance law and the power of tradition in a time of rapid economic change, 1840-1864. Environmental History 4, 565-597.

Santiago, M., 2006. The Ecology of Oil. Environment, Labor, and the Mexican Revolution Cambridge University Press, Cambridge and New York, pp. 1900-1938.

Schandl, H., Schulz, N.B., 2002. Changes in United Kingdom's natural relations in terms of society's metabolism and land use from 1850 to the present day. Ecological Economics 41, 203-221.

Sellers, C., 1997. Hazards of the Job. From Industrial Hygiene to Environmental Health Science. University of North Carolina Press, Chapel Hill and London.

Sheail, J., 2002. An Environmental History of Twentieth-century Britain. Palgrave, New York.

Sieferle, R.P., 1990. The energy system: a basic concept of environmental history. In: Brimblecombe, P., Pfister, C. (Eds.), The Silent Countdown. Essays in European Environmental History. Springer-Verlag, Berlin.

Sieferle, R.P., 2001 [1982]]. The Subterranean Forest. Energy Crisis and the Industrial Revolution. White Horse Press, Cambridge, UK.

Simmons, I.G., 2008. Global Environmental History. University of Chicago Press, Chicago.

Smil, V., 1994. Energy in World History. Westview Press, Boulder.

Smil, V., 2008. Energy in Nature and Society: General Energetics of Complex Systems. The MIT Press, Cambridge, MA.

Steinberg, T.L., 1986. An ecological perspective on the origins of industrialization. Environmental Review 4, 261-276.

Steinberg, T.L., 2002. Down to earth: nature, agency and power in history. American Historical Review 3, 798-820.

Steinberg, T.L., 2004 [1991]]. Nature Incorporated. Industrialization and the Waters of New England. Cambridge University Press, Cambridge (MA).

Tarr, J., 1996. The Search for the Ultimate Sink: Urban Pollution in Historical Perspective. University of Akron Press, Akron, $\mathrm{OH}$.

Tarr, J., 2003. Devastation and Renewal: An Environmental History of Pittsburgh and its Region. University of Pittsburgh Press, Pittsburgh, PA.

Toynbee, A., 1960 [1884]]. The Industrial Revolution. The Beacon Press, Boston.

White, R., 1995. The Organic Machine. The Remaking of the Columbia River. Hill and Wang, New York.

Wilkinson, R., 1973. Poverty and Progress. An Ecological Model of Economic Development. Methuen, London.

Wilkinson, R., 1988. The British Industrial Revolution. In: Worster, D. (Ed.), The Ends of the Earth: Perspectives on Modern Environmental History. Cambridge University Press, Cambridge and New York.

Worster, D., 1979. Dust Bowl: The Southern Plains in the 1930s. Oxford University Press, New York.

Worster, D., 1985. Rivers of Empire. Water, Aridity and the Growth of the American West. Oxford University Press, Oxford.

Wrigley, E.A., 1988. Continuity, Chance and Change. The Character of the Industrial Revolution in England. Cambridge University Press, Cambridge, UK. 